\title{
FISCAL POLICY IN THE FUNCTION OF ENCOURAGING INVESTMENT IN RESEARCH AND DEVELOPMENT IN SELECTED COUNTRIES IN THE REGION
}

\author{
MILOSEVIC Svetlana \\ ${ }^{1}$ Belgrade Banking Academy,Belgrade (SERBIA) \\ E-mail: cecaaca@eunet.rs
}

\begin{abstract}
Investing in research and development is a trend in modern business conditions, because it is expected to improve economic growth and improve competitiveness. The purpose of this paper is to analyze the fiscal policy in the surrounding countries, which invest in research and development more than Serbia does. In that way, it can be seen whether some of the analyzed measures could be applied in Serbia as well. The analysis showed that Hungary has the most extensive network of tax incentives for research and development, which records the largest investments in research and development.
\end{abstract}

Keywords: Fiscal policy, Tax incentives, Research and Development

JEL: E62

DOI: 10.5937/intrev2103169M

UDC: 336.564

330.322.3:001.891

COBISS.SR-ID 55166729 


\section{INTRODUCTION}

The world's richest economies have long recognized the importance of investing in R\&D. According to the latest available Eurostat data from 2021, the member states of the European Union (EU) spent a total of 356 billion euros on $R \& D$ in 2019 [2].

Within the EU, in 2019, Germany (110 billion euros) and France (53 billion euros) spent the most on R\&D. In the same year, Serbia spent only about 408 million euros on R\&D [2].

The experience of other countries in using tax incentives for $R \& D$ is valuable. Certainly, the most developed countries have the most experience, and they were among the first to start introducing tax incentives in practice. However, Serbia, as a country with an economic structure that can in no way be compared to the most developed countries, should analyze and use the experiences and practices of the surrounding countries, which have similar natural and social factors.

Precisely for this reason, the paper analyzes the fiscal policies of the countries with which Serbia borders, because they are closer to it not only geographically, but also in size, population, mentality, economic development and the like.

The amounts of funds spent on R\&D in 2018 and 2019 in selected countries can be seen from Table 1.

Table 1. Amounts of funds spent on research and development in 2018 and 2019

\begin{tabular}{|l|l|l|l|}
\hline \multirow{2}{*}{ Country } & \multicolumn{2}{|l|}{ R\&D expenditure } & $\begin{array}{l}\text { index } \\
2019 / \\
2018\end{array}$ \\
\cline { 2 - 3 } & 2018 & 2019 & \\
\hline Germany & 104.669 .045 .000 & 110.025 .410 .000 & 105,12 \\
\hline France & 51.837 .454 .000 & 53.427 .810 .000 & 103,07 \\
\hline United Kingdom & 41.903 .357 .000 & 44.364 .320 .000 & 105,87 \\
\hline Hungary & 2.051 .375 .000 & 2.158 .621 .000 & 105,23 \\
\hline Romania & 1.024 .770 .000 & 1.067 .442 .000 & 104,16 \\
\hline Croatia & 501.756 .000 & 600.754 .000 & 119,73 \\
\hline Bulgaria & 423.818 .000 & 512.390 .000 & 120,90 \\
\hline Serbia & 394.141 .000 & 407.918 .000 & 103,50 \\
\hline N. Macedonia & 39.071 .000 & 41.425 .000 & 106,02 \\
\hline Bosnia and Herzegovina & $:$ & 34.765 .000 & \\
\hline Montenegro* & 23.490 .000 & $:$ & \\
\hline
\end{tabular}

: data not available

*data for 2018

Data source: Eurostat, 2021 and author's calculations

From the given table, it can be seen that of the surrounding countries in 2019, the most was spent on R\&D in Hungary (2.159 billion euros). Romania (1.067 billion euros), Croatia (600.75 million euros) and Bulgaria (512.39 million euros) spent more than Serbia. Northern Macedonia (EUR 41.42 million) and Bosnia and Herzegovina (EUR 34.76 million) spent less than Serbia. No data is available for Montenegro for 2019 [2].

\section{TAX INCENTIVES FOR RESEARCH AND DEVELOPMENT IN ENVIRONMENTAL COUNTRIES WHICH ARE MEMBERS OF THE EUROPEAN UNION}

All countries bordering Serbia, which are members of the European Union, in 2019 had a higher amount of investment in R\&D than Serbia.

An analytical overview of R\&D expenditures in 2019 as a share of GDP can be seen in Table 2. 
Table 2. $R \& D$ expenditure as \% GDP

\begin{tabular}{|c|c|}
\hline Country & $\begin{array}{c}\text { R\&D } \\
\text { expenditure } \\
\text { as \% GDP }\end{array}$ \\
\hline Hungary & 1,48 \\
\hline Romania & 0,48 \\
\hline Croatia & 1,11 \\
\hline Bulgaria & 0,84 \\
\hline Serbia & 0,89 \\
\hline
\end{tabular}

Data source: Eurostat, 2021 and author's calculations

From Table 2, it can be concluded that Hungary allocates the highest percentage of GDP for R\&D $(1.48 \%)$, which is still far below the European average in 2019 of 2.19\% [1].

Given that these are countries that have incomparably different GDP, and are also, when it comes to area and population, different sizes, an attempt was made to obtain comparable data by calculating the amount of $R \& D$ expenditure per capita.

Table 3. R\&D expenditure in 2019 per capita
\begin{tabular}{|l|r|} 
Country & $\begin{array}{l}\text { R\&D } \\
\text { expenditure in } \\
2019 \\
\text { per capita }\end{array}$ \\
\hline Hungary & 220,88 \\
\hline Romania & 54,98 \\
\hline Croatia & 147,38 \\
\hline Bulgaria & 73,20 \\
\hline Serbia & 58,58 \\
\hline
\end{tabular}

Data source: Eurostat, 2021 and author's calculations

As can be seen in Table 3, the highest cost of R\&D per capita in 2019 was incurred by Hungary (220.88 euros), followed by Croatia (147.38 euros) and Bulgaria (73.20 euros). With 54.98 euros of R\&D costs per capita in 2019, Romania spent less than Serbia (58.58 euros). Precisely because Hungary and Croatia have far better indicators than Serbia, when it comes to investing in R\&D, we will analytically analyze the tax incentives for R\&D in these countries.

\section{TAX INCENTIVES FOR RESEARCH AND DEVELOPMENT IN HUNGARY}

Hungary has been offering tax incentives for R\&D since 1996. The offer is branched and it is in form of [6]:

a) tax relief,

b) exemptions from social security contributions (SSC - social security contributions), professional training contributions and KIVA (Kisvállalati Ado - optional tax for small businesses) exemptions,

c) rejection of the obligation to innovate,

d) tax credit and

e) SSC and KIVA loans.

Of the listed incentives for $R \& D$, three were presented in 2019:

- KIVA exemption of $100 \%$ (KIVA tax rate is $13.5 \%$, for doctoral students $6.5 \%$ )

- SSC loan of $9.25 \%$

- KIVA loan of $6.5 \%$.

KIVA is an optional small business tax, which replaces SSC and corporate income tax. The three new tax breaks are mutually exclusive. 
In addition to the mentioned incentives in Hungary, $R \& D$ is also encouraged by certain municipalities that provide deductions based on local business tax in the amount of $10 \%$ of direct R\&D costs. Hungary also offers income-based tax incentives based on the results of R\&D activities.

a) Tax relief for R\&D can be used up to 50 million Hungarian forints (about 139 thousand euros) per year. If the tax base is negative in the year of calculation, taxpayers can reduce the tax base over the next five years to half of the positive tax base [6].

b) Exemptions from social and vocational training contributions, as well as KIVA exemptions, imply reduced contributions for employees engaged in $\mathrm{R} \& \mathrm{D}$, as well as especially low taxes for SMEs. Exemption from contributions can be for gross salaries of up to 500,000 Hungarian forints (about 1,400 euros) per month, or up to 200,000 Hungarian forints (about 555 euros) per month for doctoral students.

All domestic companies engaged in research and development activities have the right to exemption from paying contributions. Small companies with up to 50 employees and with revenues of less than 1 billion forints (about 2.8 million euros) (OECD, 2020) are entitled to the KIVA exemption.

Companies can use only one of the exemptions, because exemptions from social contributions and KIVA exemptions are mutually exclusive.

In 2020, the rate of social security contributions and vocational training contributions was $0 \%$ (instead of $18 \%$, as projected) for researchers' salaries of up to HUF 500,000 (approximately EUR 1,400) per month. For doctoral students, the rate was $0 \%$ (instead of 8.25\%) for salaries of researchers up to 200,000 forints (about 555 EUR) per month. The KIVA tax rate (for small companies) was $0 \%$ (instead of $12 \%$ for salaries up to 500,000 forints, or 0\% (instead of 6\%) for salaries of doctoral students up to 200,000 forints per month) [7].

c) Rejection of the obligation for innovation of $0.3 \%$. The basis of this contribution is sales revenue less the value of payments to subcontractors and the cost of raw materials. Contributors for innovation are large and medium-sized enterprises. Micro and small enterprises are exempted from the obligation to pay the contribution in question.

d) Tax credit is provided to large companies $0-50 \%$ of the tax liability, medium-sized companies can realize $10-60 \%$ of the tax credit, and small as much as $20-70 \%$. How much tax credit will be approved depends on the region in which the company performs R\&D. Regional aid can be $10-20 \%$. Thus, companies are enabled to receive a tax incentive of as much as $80 \%$. The tax credit can be transferred 14 years in advance and can be used even if the company has received a grant on some basis. Only investments for own needs meet the conditions for a tax credit. The tax credit is granted to taxpayers for investment projects worth 100 million forints (about 280 thousand EUR) and more [7].

d) The tax credit on social contributions (SSC) and the tax for small enterprises (KIVA) are provided to enterprises up to a maximum of $50 \%$ of the tax liability.

In 2018, tax incentives for R\&D accounted for $27 \%$ of total government support for BERD. SMEs accounted for $83 \%$ of R\&D beneficiaries and used $10 \%$ of total support. Large firms accounted for $17 \%$ of users, but they took advantage of about $90 \%$ of tax breaks. The share of enterprises in service activities was about $59 \%$, and enterprises in the manufacturing industry had a share of $39 \%$. Companies in services used about $24 \%$ of the total amount of tax incentives, while companies from the processing industry used about $76 \%$. The total number of recipients of tax incentives for R\&D in Hungary is increasing every year, so that in 2018, about 500 users were registered. The number of SMEs is increasing every year, so that in 2018 there were more than 400 , while the number of large companies decreased (there used to be about 140, and in 2018 a little more than 80) [6].

In response to the crisis caused by the COVID-19 virus, Hungary has introduced certain changes in the provisions governing contributions and taxes. The social contribution has been reduced from $17.5 \%$ to $15.5 \%$ with effect from 1 July 2020. Also, the Small Business Tax (KIVA) has been reduced from 13\% to $12 \%$ with effect from January 1, 2020. Total government support for R\&D companies in Hungary is higher than the average in OECD countries. In 2018, R\&D support as a percentage of GDP was $0.25 \%$. In the period from 2006 to 2018, total state support to BERD as a percentage of GDP (excluding sub-national tax support IiR) increased in Hungary by $0.07 \%$, while in the same period the OECD average increased by $0.03 \%$. During this period, the intensity of business research and development in Hungary increased from $0.47 \%$ to $1.14 \%$ [6]. 


\section{TAX INCENTIVES FOR RESEARCH AND DEVELOPMENT IN CROATIA}

The first tax breaks for R\&D were introduced in 2003 and several changes have been made since then. State aid for R\&D is available in the form of tax breaks, reducing the taxable income tax base for the eligible costs of $R \& D$ projects, as well as the costs of the feasibility study.

The duration of the implementation of the project for which assistance is requested can be up to three years from the beginning of the project.

The maximum state aid for certain categories of research and development projects is [5]:

a) $100 \%$ of the eligible costs of the basic research project;

b) $50 \%$ of the eligible project costs for industrial research;

c) $25 \%$ of eligible project costs for experimental development and

g) $50 \%$ of eligible costs for feasibility studies.

Under certain circumstances, incentives for industrial research and experimental development can be increased to a maximum of $80 \%$ of eligible costs, and the level of aid for feasibility studies can be increased by $10 \%$ for medium-sized entrepreneurs and $20 \%$ for small entrepreneurs [7].

The total amount of benefits that the user can receive according to the Act is [5]:

a) for predominantly basic research up to EUR 300,000 per entrepreneur / per project;

b) for predominant industrial research up to EUR 200,000 per entrepreneur / per project;

c) for the predominant experimental development up to $€ 100,000$ per entrepreneur / per project;

d) for feasibility studies in the preparation of research activities up to EUR 50,000 per study, all in equivalent in Croatian kuna (HRK).

The total amounts can be much higher if more than $50 \%$ of research conducted on the basis of contracts, knowledge and patents, the entrepreneur contracts with organizations for research and dissemination of knowledge. In such a case, the maximum aid intensity will be [5]:

a) for predominantly basic research, the amount in HRK in equivalent to 40,000,000 euros per entrepreneur / per project;

b) for predominantly industrial research, the amount in HRK in the equivalent of EUR 20,000,000 per entrepreneur / per project;

c) for predominantly experimental development, the amount in HRK equivalent to EUR 15,000,000 per entrepreneur / per project;

d) for feasibility studies in the preparation of research activities, the amount in HRK equivalent to EUR 7,500,000 per study.

Tax relief can be obtained even if the company has received a grant on a certain basis.

\section{TAX INCENTIVES FOR RESEARCH AND DEVELOPMENT IN NEIGHBORING COUNTRIES THAT ARE NOT MEMBERS OF THE EUROPEAN UNION}

All countries bordering Serbia, which are not members of the European Union, in 2019 had a smaller amount of investment in R\&D than Serbia.

An analytical overview of R\&D expenditures in 2019 as a share of GDP can be seen in Table 4.

Table 4. R\&D expenditure as \% GDP

\begin{tabular}{|l|r|}
\hline \multicolumn{1}{|c|}{ Country } & R\&D expenditure as \% GDP \\
\hline Serbia & 0,89 \\
\hline North Macedonia & 0,37 \\
\hline Bosnia and Herzegovina & 0,19 \\
\hline Montenegro* & 0,50 \\
\hline
\end{tabular}

*data for 2018

Data source: Eurostat, 2021 and author's calculations 
As in the case of EU member states, these are countries that have incomparably different GDPs, and are also, when it comes to area and population, different sizes, so an attempt was made to obtain comparable data by calculating the amount of costs for R\&D per capita.

Table 5. Amount of $R \& D$ costs per capita

\begin{tabular}{|l|r|}
\hline \multicolumn{1}{|c|}{ Country } & $\begin{array}{r}\text { R\&D expenditure in } 2019 \\
\text { per capita }\end{array}$ \\
\hline Serbia & 58,58 \\
\hline North Macedonia & 19,94 \\
\hline Bosnia and Herzegovina & 9,96 \\
\hline Montenegro* & 37,74 \\
\hline
\end{tabular}

*data for 2018

Data source: Eurostat, 2021 and author's calculations

As can be seen in Table 5, Serbia had the highest costs for R\&D per capita in 2019 (EUR 58.58). Considering that data for 2019 are not available for Montenegro, we analyzed the data for 2018 (EUR 37.74). Northern Macedonia and Bosnia and Herzegovina have far worse results. The analysis of fiscal policy in these two countries concluded that there are no specifically defined tax incentives for R\&D. For this reason, the paper analyzes only the fiscal policy in Montenegro.

\section{TAX INCENTIVES FOR RESEARCH AND DEVELOPMENT IN MONTENEGRO}

Although the importance of tax incentives has long been recognized, the Government of Montenegro has only in the past few years made concrete efforts to make the business climate more competitive and encourage R\&D. At the end of July 2020, two reform laws in the field of innovation came into force in the parliament, and in August of the same year, they entered into force, providing a wide range of incentives and incentives for both domestic and foreign companies:

- Law on Innovation Activity and

- Law on Incentive Measures for Research and Innovation Development.

The adoption of bylaws that will further define the application of these laws in practice is still ongoing.

The Law on Innovation provides that in order to effectively implement innovation policy, provide and implement funds in order to encourage innovation, the Innovation Fund of Montenegro is established, which, among other things, has the obligation to implement innovation policies by providing and directing funds from national, international and other sources towards the development of innovative entrepreneurship and encouraging cooperation between the scientific and economic sectors [3].

The Law on Incentives for the Development of Research and Innovation defines the beneficiaries of the right to incentives [4].

One of the conditions that a legal entity performing an innovation activity must meet in order to acquire the status of a beneficiary of incentive measures is to have a scientific research or innovation program or project worth at least 25,000 euros, which has an innovation that is new to the domestic or international market. and which began to be implemented after the entry into force of this Law. There is no minimum investment threshold for individuals in a research or innovation program.

A legal entity that invests in innovation activities can also acquire the status of a beneficiary of incentive measures, and one of the conditions it must fulfill is to invest funds of at least 5,000 euros in scientific research, ie an innovative project registered in the Register of Scientific Research Projects. In order for natural persons to acquire the status of beneficiaries of incentive measures, it is necessary to invest a minimum of 2,500 euros in innovation activities.

The Law on Incentives for the Development of Research and Innovation stipulates that legal or natural persons who meet certain conditions may be entitled to incentive measures that include reduction, exemption or relief in relation to [4]:

1) Personal income tax and surtax on tax;

2) Contributions for compulsory social insurance; 
3) Corporate income tax;

4) Fees for communal equipment of construction land;

5) Use of real estate and / or land owned by the state and

6) Real estate tax.

The total amount of all reductions, exemptions or reliefs realized through the use of incentive measures for one legal or natural person may not exceed EUR 300,000 on a three-year basis.

Entities of innovation activities may use more than one incentive measure at the same time, provided that the total amount of incentive measures does not exceed the permitted limit.

Large companies can only use the incentive measure on corporate income tax.

The right to exemption from personal income tax and surtax on tax can be exercised [4]:

- Startups and spin-offs for employees or engaged persons in the amount of $100 \%$ for a period of five years from the date of establishment;

- Persons performing innovative activity for the needs of foreign legal and natural persons (freelancers), as well as inventors or innovators who earn income from innovation activity in the amount of $80 \%$ during the use of the status of beneficiaries of incentive measures;

- Persons who perform self-employment, and who invest funds in entities registered in the Register of Innovation Activities in the amount of invested funds, up to a maximum of 20,000 euros per year.

- The right to exemption from compulsory social security contributions can be exercised [4]:

- Startups and spin-offs for employees for a period of a total of three years from the date of the decision on granting the status of beneficiary of incentive measures. In the specified period, the contribution for compulsory social insurance is not paid at the expense of the employer;

- Persons employed in scientific research institutions and entities that perform scientific research, ie innovation activities, and who are additionally engaged in scientific research and innovative projects, for the contribution for compulsory social insurance at the expense of the employee and the employer, exclusively for the amount of compensation for engaging in project, for the duration of the project, up to a maximum of three years per project;

- Persons employed or engaged in scientific research institutions and entities that perform innovative activities on scientific research and innovative projects, and do not exercise the right to social insurance with another legal entity for a contribution to compulsory social insurance at the expense of the employer, for the duration of the project, up to three years per project;

- Persons performing innovative activity for the needs of foreign legal entities (freelancers), as well as inventors and innovators who earn income from innovative activities for the contribution for compulsory social insurance which can be reduced in the amount of $80 \%$ of the calculated contributions, for the period duration of the status of the beneficiary of incentive measures.

The right to exemption from corporate income tax can be exercised $[4,5]$ :

- Legal entities registered in the Register of Innovation Activities that reinvest funds from the realized profit in their scientific research, ie innovative projects;

- Legal entities that invest in other subjects of innovation activity;

- Legal entities that provide innovation infrastructure;

- Innovation Fund.

These entities can reduce the calculated corporate income tax in the amount of $100 \%$ to the amount of profit they reinvest in scientific research or innovative projects, or for invested funds in shares, stocks or donations for startups, spin-offs, scientific research institutions or funds that invest funds. in entities that perform innovation activities.

The right to reduce the fee for communal equipment of construction land can be exercised by legal entities as subjects of innovation activity for a business facility that is not of public interest if at least $75 \%$ of its total net area is used for the implementation of innovative programs or projects. The fee for communal equipment of construction land can be reduced by $50 \%$, and if the user of incentive measures changes the purpose of the facility within ten years, he is obliged to return the funds in the amount of the realized incentive.

The right to use real estate and / or land owned by the state without compensation or under conditions more favorable than market conditions can be exercised by certain legal and natural persons who have received the status of beneficiaries of incentive measures. 
The right to reduce the tax on real estate registered as business premises can be exercised by legal entities as subjects of innovation activity if the real estate is used for realization of scientific research work, ie innovative program or project on the basis of which the status of beneficiary is obtained. The calculated amount of real estate tax is reduced by $50 \%$ during the duration of the status of the beneficiary of incentive measures.

The new laws make it easier to start a business, because startups are tax-exempt for up to five years from the establishment. Also, tax and contribution reductions of up to 50\% are envisaged, as well as a $100 \%$ income tax exemption for reinvesting in innovative activities or investing in strataps. However, the real benefits of these legislative provisions cannot be seen until all the necessary bylaws have been adopted that will enable their implementation in practice.

In addition to the R\&D incentives provided by the Law on Incentives for the Development of Research and Innovation, competitions for the award of grants for scientific research projects are also announced in Montenegro.

\section{CONCLUSION}

When it comes to the countries with which Serbia borders, they have very different characteristics. Romania, Bulgaria and Croatia are members of the EU, while other countries aspire to become members. The level of R\&D funding in these countries is very uneven, as is the manner and scope of tax incentives for R\&D used by countries. In Hungary, which is a member of the EU, the use of tax incentives in the function of R\&D was institutionalized in 1996, and there are currently five different incentives available to entrepreneurs in that country. Also, in Croatia, which is also a member of the EU, entrepreneurs have more incentives at their disposal. In Montenegro, the Law on Incentive Measures for the Development of Research and Innovation was adopted only in August last year. On the other hand, Bosnia and Herzegovina, North Macedonia and Albania are still looking for better opportunities and ways to finance R\&D.

Due to all the above, the practice of conducting fiscal policy from one particular country cannot be rewritten. It is necessary to summarize and analyze information on strategies in several countries with similar natural and social factors and draw certain conclusions on fiscal policy, ie tax incentives whose application would be the most successful in the function of entrepreneurship development in Serbia.

\section{REFERENCES}

[1] Eurostat, (2020), R\&D intesity in the EU (2019 data), Available at: https://ec.europa.eu/eurostat/documents/4187653/10321624/RD_intensity_2019data_Kreslic\%C3\% $\mathrm{AD}+$ pl\%C3\%A1tno+1.jpg/eab014e5-dafc-1bb6-33c3-3b1ab5a5a5c9?t=1606313161665 [Accessed November 5th 2021.]

[2] Eurostat, (2021), GERD by sector of performance, Available at: https://ec.europa.eu/eurostat/databrowser/view/rd_e_gerdtot/default/table?lang=en [Accessed November 5th 2021.]

[3] Ing-Pro, (2020a), Zakon o inovacionoj djelatnosti, Available at: https://me.propisi.net/zakon-oinovacionoj-djelatnosti/ [Accessed November 10th 2021.]

[4] Ing-Pro, (2020b), Zakon o podsticajnim mjerama za razvoj istraživanja i inovacija, Available at: https://me.propisi.net/zakon-o-podsticajnim-mjerama-za-razvoj-istrazivanja-i-inovacija/ [Accessed November 10th 2020.]

[5] Radovic-Markovic,M., Vučeković, M.,. Marković, D. (2021).Uticaj globalizacije na inovacije u Crnoj Gori i zemljama zapadnog Balkana, Megatrend revija : međunarodni časopis za primenjenu ekonomiju, Megatrend University,Belgrade, Vol. 18 , No 3. , str. 21-33.

[6] Narodne novine, (2018), Zakon o državnoj pomoći za istraživačke i razvojne projekte, Available at: https://www.zakon.hr/z/1043/Zakon-o-dr\%C5\%BEavnoj-potpori-za-istra\%C5\%BEiva\%C4\%8Dkorazvojne-projekte [Accessed November 9th 2021.]

[7] OECD, (2019), R\&D Tax Incentives: Hungary, 2019, Available at: https://www.oecd.org/sti/rd-taxstats-hungary.pdf [Accessed November 8th 2021.]

[8] OECD, (2020), OECD Compendium of information on R\&D Tax Incentives, Directorate for Science, Technology and Innovation, December 2020. Available at: http://www.oecd.org/sti/rd-taxstats-compendium.pdf [Accessed November 8th 2021.]

\section{Article history:}

Received 15 November 2021

Accepted 17 December 2021 